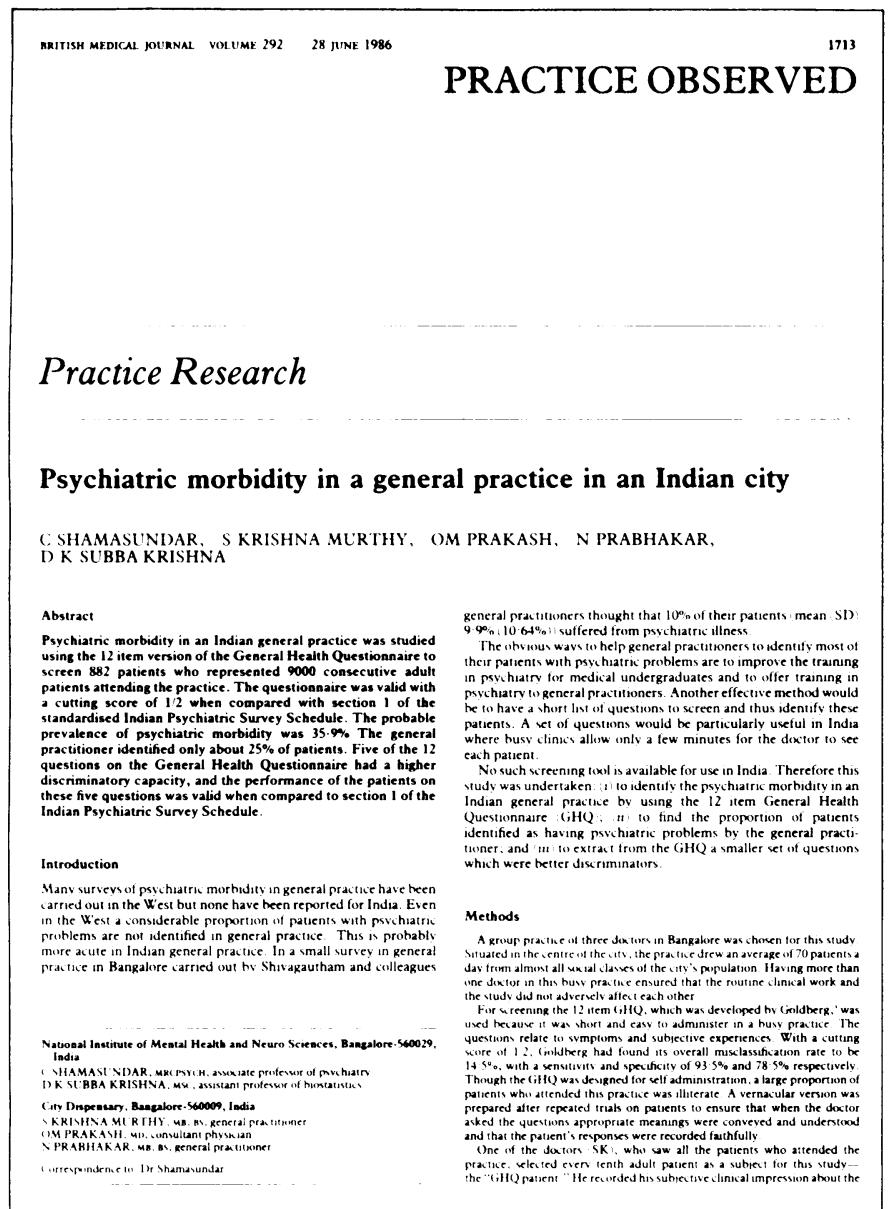

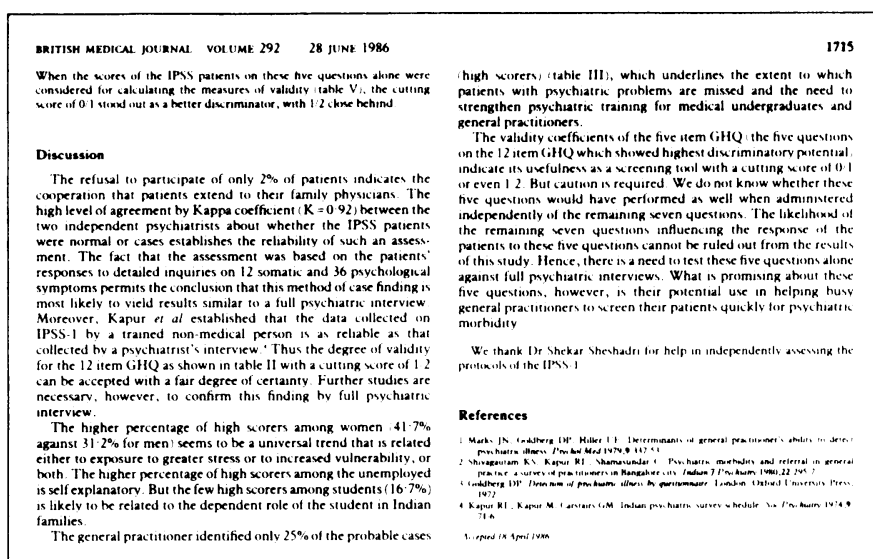

\section{Bringing the visiting diary up to date}

JAMES WILLIS

Abstract

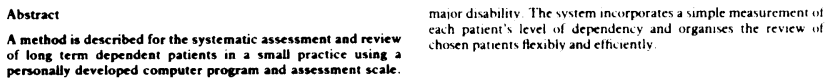
Introduccion Mechod

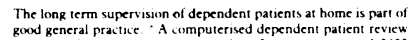

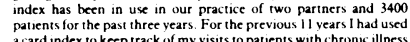

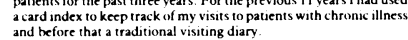

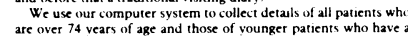

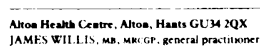

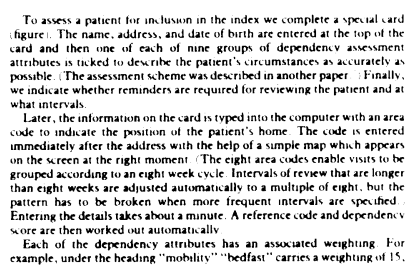

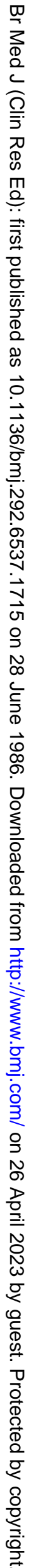

